GLOSSARY

\title{
History of addictions
}

\author{
Virginia Berridge, Sarah Mars
}

J Epidemiol Community Health 2004;58:747-750. doi: 10.1136/jech.2003.015370

This glossary arises out of research interests in the 19th and 20th century in the history of drugs, including the contemporary history of drug policy. It is necessarily brief, and British and American focused; it is also concentrated on narcotic drugs rather than alcohol and tobacco. However, the comments take on board the recent discussions of convergence across the substances, and also the spread of the concept of addiction to tobacco in recent years. The bibliography is also limited to specific interests.

See end of article for authors' affiliations

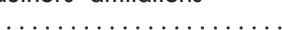

Correspondence to: Professor V Berridge, Centre for History in Public Health, London School of Hygiene and Tropical Medicine, London, UK; virginia.berridge@ Ishtm.ac.uk

Accepted for publication 22 April 2004

\begin{abstract}
ADDICTION
Contested term, first in widespread use in medicine in the early 20th century to describe compulsive drug taking. Replaced older language of "habit", "inebriety", or "morphinomania". Initially focused on alcohol and drugs, but latterly applied to nicotine, symbolising "ownership" by public health as well as by psychiatry.
\end{abstract}

\section{AIDS}

Syndrome first apparent and having an impact on the health policy arena in the early 1980s. Impact on gay men, Haitiains, black Africans initial focus of attention. The discovery and naming of the virus (HIV) and the ability to test led to awareness of its presence among groups of injecting drug users. This lead to fear that drug users might be a conduit for epidemic spread of the virus in the general population. Impact on drug policy variable between countries dependent on factors operative in drug and health policy pre-AIDS. In Britain and some other European countries it led to significant emphasis on harm reduction (see below). Impact on harm reduction in the US more limited.

\section{ALKALOID}

Active principal of drug, some of which were isolated in early part of 19th century and connected with emergent pharmaceutical industry. Codeine and morphine (known also in contemporary parlance as "morphia") were early alkaloids, derived from opium, along with lesser known thebaine, papervarine, and noscapine. Heroin was a semi-synthetic, the product of a process that modified the original alkaloid, in this case morphine. First isolated in 1874 at St Mary's Hospital in London and then rediscovered in Germany in the 1890s, marketed by Bayer under the trade name "heroin".

\section{ANSLINGER}

Harry Anslinger was the first Commissioner of Narcotics, heading the American Federal Bureau of Narcotics (FBN) from 1930-62. Identified with public policy directed at non-medical or criminal user and focused on strict law enforcement. Strong supporter of marijuana regulation after 1937 in the USA. In the 1950s exponent of view that communist China exporting heroin to undermine the West. (see below, international drug control)

\section{BRITISH SYSTEM}

Term used to describe the trend in British drug policy (see below) to permit medical prescribed maintenance doses of opioids in cases of intractable addiction where normal functioning otherwise impossible. Said to have originated in the 1920s with Rolleston Report (see below) but in fact a normal procedure well before then. Often used erroneously to describe current, or recent, policy in Britain.

\section{CANNABIS}

General term used to describe the various products of the plant Cannabis sativa. The resinous exudation of the flowering top and leaves is often known as hashish; and the material derived from chopping the leaves, buds, and stalks is called marijuana. The activity of both is largely attributable to tetrahydrocannabinol or THC. In the 19th century cannabis had some popularity in western countries for its analgesic and sedative effects. Its relation to insanity in Egypt was disputed and led to its scheduling under the 1925 Geneva Convention. (see below, "international drug control")

\section{CHLORODYNE}

One of the best known of the 19th century opium based patent preparations. Its main constituents then were chloroform and hydrochlorate of morphia, although some analysts detected a small quantity of Indian hemp.

\section{COCAINE}

An alkaloid produced from the coca leaf, which comes from the shrub Erythroxylon coca, growing in Peru and other parts of South America. Cocaine (hydrochloride) was first isolated by Niemann in 1860, gaining popularity for both its physical and psychoactive effects. It has had a diminishing medical role as an effective local anaesthetic in dentistry, ophthalmology, and ear, nose and throat surgery because of its ability to numb the surface and reduce bleeding. It was widely used in the late 19th and early 20th centuries in a variety of semi-popular forms, such as coca wines and Coca Cola. 
Other forms of cocaine, delivering the active ingredient in a more potent form, appeared in the 1970s and '80s as "freebase" and "crack". Freebase production was risky as it used an explosive organic solvent; a simpler, less flammable procedure using baking soda, produced "crack" cocaine, which became popular in the United States in the 1980s.

\section{DEPENDENCE}

A term that was introduced by the World Health Organisation in 1964 to replace "addiction" and "habituation", drawing on both psychological and physical dimensions of compulsive drug use and important at international level in International Classification of Disease (ICD). Bringing together these two ideas under one term widened the range of substances considered to have "dependence" potential. The more behavioural concept of dependence emphasised the user's strong desire or sense of compulsion to take the drug and their increasing difficulty controlling their substance taking behaviour, so embracing cocaine use, tobacco, and cannabis smoking.

\section{DE QUINCEY}

Thomas De Quincey, author of Confessions of an English Opium Eater, published in 1821, often identified as quintessential early "junkie", although in fact his opium use was always controlled. Along with Samuel Taylor Coleridge and others, part of the group of Romantic writers who used opioids for part recreational and part medical reasons. Important as symbolic example of controlled drug user and example of mind altering powers of drug use.

\section{GODFREYS CORDIAL}

A "childrens' opioid" of which there were many in the 19th century, based on laudanum (see below). Other children's soothing syrups included Mrs Winslow's Soothing Syrup, Atkinson's Infants Preservative, and Street's Infants Quietness.

\section{HABIT}

Pre-addiction term used to describe compulsive drug taking, but without medical connotations. To be "in the habit of" taking such substances/medicines was not necessarily a condition arousing disapproval. In 1957 a World Health Organisation Expert Committee distinguished "drug habituation" from "drug addiction" on the basis of the absence of physical dependence and little or no tendency to increase the dose, but dropped both terms in 1964, replacing them with the single drug "dependence"

\section{HARM REDUCTION}

A policy approach accepting certain drug use and drug taking behaviours, such as injecting, and aiming to reduce the associated individual and public health risks, for example, through supplying sterile needles (see "needle exchange schemes") or pharmaceutical supplies of the same or a similar drug. This approach had its antecedents in British drug policy stretching back to the 19th century, falling from favour in the late 1970s and early 1980s when treatment orthodoxy favoured an abstinence based approach. Following the policy response to AIDS, supporters of harm reduction approaches inside and outside government lobbied successfully for its revival and it became official British policy from 1988 onwards.

\section{HARRISON ACT}

Harrison Narcotic Act passed in the US on 14 December 1914, taking effect in 1915. Part of American support for international drug control (see below), it was a revenue measure. Anyone dealing in the specified drugs had to register and buy tax stamps. Federal authorities retained records of transactions in the regulated drugs. Legal decisions under the act brought about the end of maintenance experiments among US physicians and the intensification of a black market for drugs.

\section{HYPODERMIC SYRINGE}

Technological innovation of the 1840s and '50s. Dispute between Dr Alexander Wood of Edinburgh and Dr Charles Hunter in London about whether the method had local or general effects settled in favour of Hunter's "general" thesis. Initially praised in the medical literature as a safer and less habit forming mode of administering opioids.

\section{INEBRIATE}

Term covering users of both alcohol and liquid forms of habit forming drugs. The term replaced the use of "habitual drunkard" and control of inebriety grew in importance as a policy objective. Medical men and others aimed to secure compulsory committal of inebriates (to both drink and drugs, although primarily the former) through the enactment of inebriates legislation but were unsuccessful. Diffusion of the concept in the UK owed much to the work of the Society for the Study (and Cure) of Inebriety, founded in 1884 out of an earlier habitual drunkards organisation. The concept and associated policy symbolised the inter-relation between penal and medical forms of control.

\section{INTERNATIONAL DRUG CONTROL}

Internationalism has been a key feature of anti-substance alliances. In 1878 the first international alcoholism congress was held in Paris. In 1906 the first international association was set up and located in Lausanne. But alcohol was never a serious candidate for overall international regulation. The closest approximation to international effort was the African based regional control arrangement agreed between the parties to the General Brussels Act of 1889-90 and included in the antislavery provisions of the act.

The opioids, by contrast, developed an international control system that has dominated and helped to determine systems of domestic regulation. An earlier draft regional system (set up by the Shanghai Opium Commission in the early 1900s) transmuted through American efforts, in their turn prompted both by missionary concerns and strategic imperatives, into a nascent global system before the first world war. Germany and Britain resisted but the post-war settlement saw these export controls imported into the peace settlement under the supervision of the League of Nations. The 1925 Geneva Convention, which scheduled cannabis for the first time, was part of this system.

This system of control of trade changed after the second world war, again under American influence, into a strongly prohibitory regime whose impact continues to be felt in smuggling, the illicit trade, and in domestic drug control legislation. Control, as it changed, helped to exacerbate the problem it had been set up to deal with.

\section{LAUDANUM}

One of the many opium based preparations on sale in the 19th century and beyond. It was otherwise known as tincture of opium, made by mixing opium with distilled water and alcohol. Other preparations included paregoric, or camphorated tincture of opium (paregoric is derived from the Greek word for soothing or consoling); Battley's Sedative Solution, officially known as liquor opii sedatives, opium mixed with calcium hydrate, alcohol, sherry, and water; and Dovers Powder, a preparation first made by Dr Thomas Dover and widely used in hospital practice in the 19th century. 


\section{LEGALISATION}

Opponents of current systems of drug control, especially at the international level, often call for "legalisation" or "liberalisation" of drug policy. There is reference to the "war on drugs", a term used by both pro-drug and antidrug reformers

What is meant by legalisation is often unclear or has different meaning in different contexts. In recent years, there have been calls for greater convergence between policies towards illicit drugs, alcohol, and smoking, which are seen by reformers as illogical in terms of harm reduction.

\section{MAINTENANCE}

Term used to describe the practice of prescribing opioid based drugs like morphine or heroin to those who could only function normally by taking them. Maintenance in a non-medical sense was the norm for habitual users in the 19th century and before, but this became a medicalised activity in the early 20th century; its legitimacy in Britain was cemented by the 1926 Rolleston Report (see below). Maintenance was not a legitimate activity in the US after the enforcement of the Harrison Act (see entry) and was only reintroduced in the 1960s in New York through the use of methadone.

\section{METHADONE}

Synthetic opioid first synthesised in the German pharmaceutical industry in the inter-war years and patented in 1941. Rediscovered in the 1960s as a treatment or long term maintenance for opioid addicts in New York by physicians Vincent Dole and Marie Nyswander. They believed that heroin addiction created a permanent metabolic change in the body, explaining the frequency of relapse, so that methadone maintenance might be necessary for the life of the addict. Their theory contrasted with existing psychoanalytical approaches to addiction and coincided with the chemotherapeutic revolution taking place in psychiatry during the 1950s and early 1960s. US health services took up the new form of treatment and by 1970 New York City had 20000 patients. Physicians came from across the world to train with Dole and Nyswander and export the treatment to their own countries.

\section{NARCOTIC}

Technically narcotic drugs are those that have a sedative and sleep inducing effect, such as opium and opioids, but the term has been applied in control legislation to drugs like cannabis and cocaine that have quite different pharmacological effects.

\section{NEEDLE EXCHANGE SCHEMES}

The AIDS crisis saw needle exchange schemes became accepted practice in the UK, when concern arose about the spread of HIV through drug users sharing contaminated injecting equipment. Needle exchange schemes have been introduced in other countries around the world, but in some, such as the United States, they remain highly controversial.

\section{OPIUM}

The product of the opium poppy, Papaver somniferum, a white poppy growing to a height of one or two feet. This poppy is or has been grown chiefly in Asia Minor, China, Iran, and some Balkan countries.

\section{OPIUM SMOKING}

A mode of ingesting the drug practised in some Far Eastern countries. Particularly associated with China and the "Opium Wars" of the mid-19th century. Recent scholarship has emphasised that opioid use and smoking was an indigenous custom that had positive as well as negative aspects.

The export of opium smoking into the white races and into settings in the UK and US was a matter of concern in the late 19th and early 20th centuries. The practice in fact seems to have been quite limited and the concern was symbolic of contemporary concerns for racial and social purity rather than the response to an empirical "problem". In recent years, the practice of "chasing the dragon"-inhaling the heated vapours of heroin through a tube-has built on the earlier practice and imagery of opium smoking.

\section{"OPIUM WARS"}

These two wars, waged by the British against the Chinese from 1839 to 1842 and from 1856 to 1858 , represented the military pursuit of commercial imperialism. British trading policy, with the support of the Indian government, had permitted the East India Company a monopoly of trade with China that had ended in 1834. The Company cultivated and sold opium in India, and distributed it in China. Opposition from the Chinese Emperor to the influx of opium into his country led to his enforcing anti-opium laws, publicly confiscating and destroying a large quantity of imported opium. Britain seized this opportunity as provocation to fight for greater access to Chinese markets and pursue free trade, which it gained through the 1842 Treaty of Nanking. The second opium war was declared by the British on an even slimmer pretext, with involvement from France, Russia, and the United States, who gained further trade concessions from the resulting Treaty of Tientsin.

\section{PROBLEM DRUG USER}

Term redolent of the 19th century use of "habit" but also deriving from the 1930s eugenic discussions of "the problem family" and the "social problem group", which in turn had echoes of the late 19th century concept of the "residuum". First used for alcohol and drug users in the 1970s in place of "addict" or "drug dependent", and in more widespread use in the 1980s and after. Symbolised decline of disease specific views of compulsive drug taking and also the involvement of a wider range of personnel in the management of drug issues.

\section{PROHIBITION}

System of alcohol control put in place in the US in 1920 and repealed in 1933. Prohibition has had bad press and often seen as automatic failure, with the development of a large black market. Historical assessment however is more nuanced and emphasises the differential impact of prohibition at different points in time and across the various states. Its early years in the US were more successful than later, and it had strong public support in the rural South and West. The end of Prohibition was influenced by the Great Depression from 1929, as the opportunity to gain substantial taxation from alcohol, at a time when taxation revenues had fallen, was appealing to government. Canada also experimented with Prohibition from 1915 but similarly abandoned the policy. The term is often used now to condemn all stringent regulatory regimes in a non-specific way.

\section{ROLLESTON REPORT}

Departmental Report on Morphine and Heroin Addiction published in 1926 and called after its chair, Sir Humphrey Rolleston. After the implementation of international drug control requirements through the first Dangerous Drugs Act

\section{Policy implications}

Policy implications are that an understanding of history may help the formulation of policy for drugs 
(1920) the Home Office aimed to implement a system akin to that being established in the US at the same period. This proved impossible and the publication of the report marked the legitimisation of medical prescribing, albeit within an overall system of penal control. Often wrongly characterised as having "caused" Britain's low numbers of drug users, but in fact the outcome of that lack of a problem rather than the cause.

\section{VIETNAM WAR}

The Vietnam war was important in providing justification for changing drug policy in the United States. Research showed that returning soldiers were able to stop the drug use that had become widespread in Vietnam; this provided support for the view that drug use was dependent on situation and context rather than intrinsic and intractable. Part of a change in policy also associated with the provision of methadone based treatment (see above, methadone).

\section{LIST OF KEY READING}

Berridge V. Opium and the people. Opiate use and drug control policy in nineteenth and early twentieth century England. London: Free Association Books, 1999. (Expanded edition)

Berridge V. AIDS and British drug policy: continuity or change? In: Berridge V, Strong P, eds. AIDS and contemporary history. Cambridge: Cambridge University Press, 1993,:13556.

Berridge V. AIDS in the UK. The making of policy, 1981-1994. Oxford: Oxford University Press, 1996.

Burnham J. Bad habits: drinking, smoking, taking drugs, gambling, sexual misbehaviour and swearing in American history. New York: New York University Press, 1993.
Courtwright DT. Dark paradise. Opiate addiction in America before 1940. Cambridge, MA: Harvard University Press, 1982.

Courtwright DT. The prepared mind: Marie Nyswander, methadone maintenance, and the metabolic theory of addiction. Addiction 1997;92:257-65.

Courtwright DT. Forces of habit. Drugs and the making of the modern world. Cambridge, MA: Harvard University Press, 2001.

Edwards G, ed. Addictions. Personal influences and scientific movements. New Brunswick: Transaction Publishers, 1991.

Edwards G, ed. Addiction. Evolution of a specialist field. Oxford: Blackwell Scientific, 2002.

Gootenberg P, ed. Cocaine. Global histories. London: Routledge, 1999.

McAllister WB. Drug diplomacy in the twentieth century. London: Routledge, 2000.

Musto D. The American disease. Origins of narcotic control. New York: Oxford University Press, 1987. (Expanded edition)

Newman R. Opium smoking in late Imperial China: a reconsideration. Modern Asian Studies 1995;29:765-94.

Royal College of Psychiatrists and Royal College of Physicians. Drugs: dilemmas and choices. London: Gaskell, 2000.

\section{ACKNOWLEDGEMENTS}

Both authors are grateful to the Economic and Social Research Council and to the Wellcome Trust, whose funding has supported research on which this glossary is based. We would also like to thank Stuart Anderson for his advice on pharmacy history.

\section{Authors' affiliations}

V Berridge, S Mars, Centre for History in Public Health, London School of Hygiene and Tropical Medicine, UK

\section{Call for papers}

10th European Forum on Quality Improvement in Health Care 13-15 April 2005, ExCel, Docklands, London For further information on how to submit your paper please go to: http://www.quality.bmipg.com 